https://doi.org/10.52240/1857-2367.2020.2(21).45

\title{
SOME BIOLOGICAL FEATURES AND GREEN MASS QUALITY OF
} INULA HELENIUM

\author{
Ana GUŢU, Cristina TENTIUC, Dragoş COVALCIUC, Victor ŢÎTEI, Serghei COZARI \\ "Al. Ciubotaru” National Botanical Garden (Institute), \\ Chisinau, Republic of Moldova
}

Abstract: We have studied some biological features, the particle size distribution in chopped mass, and the biochemical composition and have estimated the biomethane potential of aerial biomass of the 'Ileana' cultivar of Inula helenium in the second growing season.

Key words: biochemical composition, biological features, biomethane, Inula helenium 'Ileana', particle size distribution. 
Asteraceae is one of the largest families of flowering plants, with about 11,000 genera and about 23,000 species, most of them are herbs or shrubs; they are rarely twiners or trees. The genus Inula L., placed in the subfamily Asteroideae, tribe Inuleae, comprises of about 100 species distributed in Asia, Europe and Africa. The species of this genus are known as honey plants and medicinal plants, which contain various biologically active compounds with anticancer, antibacterial, hepatoprotective, cytotoxic and anti-inflammatory properties. In the flora of the Republic of Moldova, nine species have been identified so far, including Inula helenium L.. The objectives of this research were to study some biological features of Inula helenium L. grown in monoculture under the climatic conditions of the Republic of Moldova, to evaluate the particle size distribution in chopped mass and the biochemical composition of green mass and the possibility to use it as feedstock for the production of biomethane.

The cultivar 'Ileana' of elecampane, Inula helenium L., bred in the "Alexandru Ciubotaru" National Botanical Garden (Institute) and grown in monoculture on the experimental land in Chisinau, N 46 58 $25.7^{\prime \prime}$ latitude and E 28 $8^{\circ} 52^{\prime} 57.8^{\prime \prime}$ longitude, served as subject of the research. The experiment was conducted in a randomized complete block design with four replications; planting was done on May 15, according to the scheme $70 \mathrm{~cm} \times 35 \mathrm{~cm}$. The plant growth, development and productivity were assessed according to standard methodical indications. The harvested whole plants were chopped into chaff with the use of a stationary forage chopping unit. The particle size distribution was determined using standard sieves. The main biochemical parameters: crude protein $(\mathrm{CP})$, crude fibre (CF), ash, acid detergent fibre (ADF), neutral detergent fibre (NDF), acid detergent lignin (ADL), hemicellulose (HC) and cellulose (Cel) have been determined by NIRS technique using the PERTEN DA 7200 analysis system. The biochemical methane potential was calculated according to the equations of Dandikas et al., 2014. [1]

It was found that, during 30 days after planting, the growth and development was very slow. Certain intensification was observed in the second half of summer, by the end of the growing season, the plants developed a rosette of 5-11 leaves with yellowish-green on the upper surface and greyish-green on the dorsal. The fresh mass productivity was $236 \mathrm{~g} / \mathrm{plant}$. In the $2^{\text {nd }}$ year, the growing season started in the middle of April, the formation of generative shoots - in May, the budding stage - at the middle of June, the flowering stage in July - middle of August, fruit ripening stage August - September. The lower basal leaves were $45-67 \mathrm{~cm}$ long and $15-20 \mathrm{~cm}$ broad; the central leaves $-22-$ $43 \mathrm{~cm}$ long and 9-14 mm broad; and, in top sections, the leaves varied in length from 9 to $20 \mathrm{~cm}$ and in width - from 3 to $5 \mathrm{~cm}$. The plants of the cultivar 'Ileana', in the budding stage, reached $178-186 \mathrm{~cm}$ and in full flower stage reached $204-232 \mathrm{~cm}$, developed 12-28 flower heads of 45-62 $\mathrm{mm}$ in diameter, with bright yellow ligulate ray florets and golden-yellow disk florets. When harvested in the bud formation stage, the weight of a shoot was $332.8 \mathrm{~g}$ fresh mass or $70.4 \mathrm{~g}$ dry matter, but in full flower stage $-440 \mathrm{~g}$ fresh mass or $112.6 \mathrm{~g}$ dry matter.

It was established that the chopped fresh mass contained $33.1 \%$ particles larger than $16 \mathrm{~mm}, 46.2 \%$ particles of $8-16 \mathrm{~mm}, 17.3 \%$ particles of $3.15-8 \mathrm{~mm}$ and $3.4 \%$ particles of 0-3.15 mm. The harvested whole plants were characterized by $348 \mathrm{~g} / \mathrm{kg} \mathrm{DM}, 103 \mathrm{~g} / \mathrm{kg} \mathrm{CP}$, $337 \mathrm{~g} / \mathrm{kg}$ of CF, $350 \mathrm{~g} / \mathrm{kg}$ ADF, $593 \mathrm{~g} / \mathrm{kg}$ NDF, $57 \mathrm{~g} / \mathrm{kg}$ ADL, $68 \mathrm{~g} / \mathrm{kg}$ ash, $293 \mathrm{~g} / \mathrm{kg} \mathrm{Cel}$, 
$173 \mathrm{~g} / \mathrm{kg} \mathrm{HC}$. The biochemical methane potential of fresh mass substrate 280 litre $/ \mathrm{kg}$ VS. The cultivar 'Ileana' of Inula helenium L. in monoculture produces good yields with optimal particle size distribution and biochemical composition of green mass, can be used as feedstock in biogas reactors and renewable energy production.

The research was supported by the NARD through the project "Mobilization of Plant Genetic Resources, Plant Breeding and as Forage, Melliferous and Energy Crop in Bioeconomy", 20.80009.5107.02

\section{BIBLIOGRAPHY}

1. Dandikas V., Heuwinkel F., Drewes J. E., Koch K., Correlation between biogas yield and chemical composition of energy crops. Bioresource Technology, 2014, 174, p. 316-320. 